\title{
Caries in children with lactose intolerance and cow's milk protein allergy
}

\author{
Suzely Adas Saliba MOIMAZ(a) \\ Marcelo Augusto AMARAL(a) \\ Cléa Adas Saliba GARBIN(a) \\ Tânia Adas SALIBA(a) \\ Orlando SALIBA ${ }^{(a)}$
}

(a) Universidade Estadual Paulista - Unesp, School of Dentistry, Department of Pediatric and Social Dentistry, Araçatuba, SP, Brazil.

Declaration of Interest: The authors certify that they have no commercial or associative interest that represents a conflict of interest in connection with the manuscript.

\section{Corresponding Author:}

Suzely Adas Saliba Moimaz

E-mail: sasaliba@foa.unesp.br

https://doi.org/10.1590/1807-3107bor-2018.vol32.0091

Submitted: April 10, 2018

Accepted for publication: June 27, 2018

Last revision: July 18, 2018
Abstract: Dental caries in 5-to-8-year-old children with cow's milk protein allergy (CMPA) and lactose intolerance (LI), their treatment needs, and the consumption of milk-based products and milk derivatives by these patients were investigated. A cross-sectional study was undertaken with 200 children in southern Brazil in 2017. The clinical examination was based on the World Health Organization criteria and a questionnaire was sent to parents or legal guardians to collect information on the children's food intake, pre-existing systemic diseases, medication use, and CMPA and LI. Standardization was performed to verify concordance among examiners (kappa $=0.96$ ). Caries prevalence was $67.50 \%$ in children with CMPA or LI, but $34.37 \%$ in those without these conditions. The mean $\mathrm{dmft}$ (decayed, missing, and filled teeth) index in children with CMPA or LI was $1.75 \pm 1.84$, significantly higher than among non-allergic or lactose-tolerant children $(0.83 \pm 1.60)(\mathrm{p}$ $<0.001$ ). In children with CMPA or LI, the mean for treatment needs was $1.58 \pm 1.50$. Lactose-free milk was the most frequently consumed food among allergic/intolerant children (65.00\%), with a mean dmft of $2.00 \pm 2.08$, higher than that obtained for those without CMPA/LI ( $0.82 \pm 0.87)$, showing no significant difference $(p=0.129)$. Although dental caries and treatment needs in primary dentition were associated with CMPA or LI, children's intake of replacement foods did not pose any risk for the development of carious lesions. Statistically significant differences were obtained for the prevalence and severity of dental caries. This shows the need for treatment of children with CMPA or LI, who had the worst caries prevalence and severity rates.

Keywords: Dental Caries; Milk Hypersensitivity; Lactose Intolerance.

\section{Introduction}

Food allergy is a public health concern since it affects 6 to $8 \%$ of children and $2 \%$ of adults worldwide. ${ }^{1,2}$ Its self-reported prevalence in adults and children in European populations hovers around $5.9 \%$ and $6.9 \%$, respectively. ${ }^{3}$ Cow's milk protein allergy (CMPA) is the most common allergy in children. ${ }^{4,5}$ Although rare, there have been reports in recent decades on an increase in CMPA prevalence. In fact, severe food allergy has been currently the main cause of emergency care in the hospital setting. ${ }^{6}$

CMPA may be defined as an adverse immunological reaction to one or more cow's milk proteins. ${ }^{7}$ The reaction involves immunoglobulin $\mathrm{E}$ (IgE), lymphocytes $\mathrm{T}$, or both, affecting 2-3\% of children. ${ }^{4}$ There is no consensus among patients and physicians about lactose intolerance (LI) and CMPA. 
Several discussions on the nomenclature of allergic reactions to milk and on diagnosis have ensued in the past 15 years. ${ }^{8}$ The current nomenclature has been determined by the mechanisms that most probably cause the symptoms. CMPA is mediated by IgE. LI is the reduced capacity of the small intestine to digest lactose and it is not immune-mediated. ${ }^{8,9}$

In Brazil, $43 \%$ of white and mixed-race adults have LI, but it is more frequent among black people and among individuals of Japanese ancestry, with typical and systemic symptoms. Typical symptoms include bellyache, bloating, flatulence, diarrhea, stomach rumble, and vomiting, especially in young people. Feces are bulky, foamy, and watery. ${ }^{10}$ In the case of systemic symptoms, it must be ascertained that they are really caused by food intolerance, or rather, whether they are coincident symptoms or derived from CMPA (affecting 20\% of people with LI symptoms). ${ }^{11}$

Total and/or definitive exclusion of lactose from the diet of children with CMPA or LI depends on a precise medical diagnosis and normally involves soy-based formulas or other milk substitutions, sweetened or not with sucrose and nutritionally adequate, ${ }^{12}$ whose capacity to cause enamel demineralization of deciduous teeth and to form biofilm is poorly known. ${ }^{13}$

Children with special healthcare needs, such as those with fragile $\mathrm{X}$ syndrome ${ }^{15}$, growth disorders, gastroesophageal reflux, and IL, are prone to oral diseases. ${ }^{14}$ Dentists are, therefore, better prepared to identify children at high risk for dental caries and other oral diseases, which allows for an early intervention. ${ }^{16}$

Studies on the dental conditions of children with CMPA or LI are highly relevant because they assess caries prevalence and other oral diseases that affect this specific group. Most studies on CMPA or LI patients deal with medical and nutritional aspects. ${ }^{25,8,17}$ In fact, scanty information is available on the oral conditions of children with CMPA or LI. ${ }^{18,19}$ The topic is rarely investigated. The present study analyzes the prevalence and severity of dental caries and the treatment needs of 5-to-8-year-old children with CMPA or LI. Some factors related to this specific health condition are also evaluated.

\section{Methodology}

The present cross-sectional study analyzes the prevalence and severity of dental caries, treatment needs, and the intake of supplemental formulas by children attending a private school in a town in southern Brazil, in 2017.

\section{Study population and data collection}

The study population was comprised of male and female 5-to-8-year-old children. This specific age bracket was chosen since primary LI mainly manifests itself after 6 years in white individuals. ${ }^{20}$ Prior to the clinical examination, a food frequency questionnaire (FFQ) was sent to parents or legal guardians for evaluation of children's consumption of milk, milk derivatives, and other foods. Whether or not the children had CMPA or LI, all parents or legal guardians answered the FFQ. In addition to the FFQ, another questionnaire including data on CMPA and its duration, LI and its duration, systemic disease, and use of medications was sent out. It should be underscored that CMPA and LI were either identified through parents' or legal guardians' responses to the questionnaires or self-reported.

The distinction between the two diseases in the questionnaire was based on the description of the main symptoms. LI is characterized only by gastrointestinal symptoms (abdominal pain, flatulence, and diarrhea), while CMPA has gastrointestinal, dermatological, and/or respiratory symptoms. ${ }^{8}$

The sample size was based on an error rate of $5 \%$ and on a $95 \%$ confidence interval. Prevalence of lactose malabsorption was estimated at $10.5 \%{ }^{21}$ and the minimum sample size was set at 145 children. Since dental caries and treatment needs of the study population were evaluated, the sample size was larger in order to make up for possible losses. In fact, the number of children in the current study was 200 .

A pilot study with 10 children of the same age was undertaken. These children were not chosen for the final sample, which included a health questionnaire and FFQ pretest. The intra-examiner calibration consisted of a 4-hour theoretical step on the dental indices used and of a 16-hour practical step involving tests and discussions with the first author of the present 
paper. ${ }^{22}$ Tests were performed in duplicate in $10 \%$ of the sample (20 children). Kappa statistics was used to calculate reproducibility, with one tooth as the diagnostic unit, following the methodology proposed by Peres et al. ${ }^{22}$ These tests aimed at benchmarking the diagnostic reliability of the initial examination. The kappa coefficient was 0.96 .

The final sample included the children who returned the FFQ, the questionnaire on health conditions, and the signed free consent form. Later, the children were subjected to an oral clinical examination. Children with severe systemic or neurological diseases, with viral diseases, who were wearing orthodontic appliances, and who did not forward all the required documents to the school authorities after three school visits were excluded from the study.

If treatment needs or immediate dental care were detected during the examination, the child was taken to a basic health unit for proper treatment.

\section{Food frequency questionnaire for adolescents}

The food frequency questionnaire for adolescents (FFQA), prepared by Slater et al. ${ }^{23}$ to evaluate the amount of food consumed throughout 6 months, was adapted and employed in the current research. Adaptation was required since FFQA failed to include soy-based foods. FFQA was validated by Marchioni et al. ${ }^{24}$ and proved to be satisfactory.

FFQA comprises 76 food items or food groups, featuring approximately $90 \%$ of the energy and macronutrients consumed by children and adolescents. The list of items was based on the data on food consumed in the last 24 hours. Each food item in the questionnaire comprised seven categories, and both the amount and frequency of food consumption were recorded. Categories, determined in quantities (standard portion) consumed during the day, were characterized as lack of intake ('never') and frequency ('twice a day or more')

The questionnaire was sent out to the parents or legal guardians, who were invited to estimate the mean frequency of food intake during the past 6 months, choosing one out of seven categories: "never," "less than once a month," "once to three times a month," "once a week," "twice to four times a week," "once a day," or "twice a day or more."
The following food types were included in the categories: whole milk, semi-skimmed milk, or skimmed milk; plain yogurt or fruit yogurt; chocolate milk; lactose-free milk; whole soy milk; soy milk powder; soy yogurt; chocolate soy milk; soy milk fruit juice; other types of milk.

The foods described above were classified as high, moderate, and low consumption. High-consumption foods are those eaten once a day or twice a day or more; moderate-consumption foods are eaten twice to four times a week; any other options indicated low-consumption foods.

Results included only those foods with a consumption greater than $15 \%$ in the moderate and low consumption categories.

\section{Clinical examination}

All of the children participated in activities related to oral health in the first clinical evaluation. They received toothbrushes and performed supervised toothbrushing. After the first contact with the children, a trained examiner performed the dental clinical examination.

All the children were examined in a room within the school premises, under good natural lighting. When necessary, illumination was provided by a portable flashlight. The examiner wore surgical mask and gloves and performed the examination in the standing position. He used probes with ball tips and previously sterilized plane mouth mirrors in compliance with biosafety standards.

The codes and criteria for classification followed the fourth edition of the Oral HealthSurveys, Basic Methods ${ }^{25}$ for retrieval of clinical data on dental conditions (dmft) and the index of treatment needs (ITN).

The field team consisted of an examiner (the second author) and a note taker (an undergraduate dental student) who had to write down the details of the clinical examination.

\section{Data processing and analysis}

BioEstat v. 5.3 (Instituto Mamirauá, Manaus, Brazil) and EpiInfo v. 7.1.5 (Centers for Disease Control and Prevention, Atlanta, USA) were employed for data processing. The Mann-Whitney $U$ test was used to test $\mathrm{dmft}$ and ITN indices in the groups with and without CMPA or LI. The chi-square test was used to 
analyze proportions (prevalence of dental caries and treatment needs) between the groups. Nonparametric tests were employed since the $\mathrm{dmft}$ index did not have a normal distribution. Statistical significance was set at $5 \%$.

\section{Ethical aspects}

The study was approved by the Research Ethics Committee of the Centro Universitário de Maringá (UniCesumar), process number 2.028.098/2017, and complied with Resolution 466/2012 of the Brazilian Health Council. Parents or legal guardians received information on the aims of the study and signed the consent form for the participation of their children.

\section{Results}

\section{Sample description}

The present study on children's oral health carried out in a town in southern Brazil revealed a balanced distribution between patients' age and sex, with a slight predomination of 6-year-old children $(36.50 \%)$ and males $(59.00 \%)$. Six children (3.00\%) had only CMPA, $37(18.50 \%)$ had only LI, and three (1.50\%) had both CMPA and LI. Forty children (20.00\%) were allergic to cow's milk protein or intolerant to lactose. Intolerance duration ranged from 12 to 92 months. In addition, drug treatment of lactose malabsorption was identified in seven children $(17.50 \%)$ with CMPA or LI (Table 1$)$.

Table 1. Epidemiological and clinical characteristics of children $(n=200)$. Paraná, Southern Brazil, 2018.

\begin{tabular}{|c|c|c|c|c|}
\hline Variables & Total $(n=200)$ & $\begin{array}{l}\text { Children without CMPA + LI } \\
\qquad(n=160)\end{array}$ & $\begin{array}{l}\text { Children with CMPA + LI } \\
\qquad(\mathrm{n}=40)\end{array}$ & $\mathrm{p}$-value \\
\hline Age (years) & $05-08$ & $05-08$ & $05-08$ & \\
\hline mean $\pm S D$ & $6.26 \pm 0.94$ & $6.23 \pm 0.96$ & $6.38 \pm 0.81$ & \\
\hline Median & 6 & 6 & 6 & 0.263 \\
\hline Age range & $\mathrm{n}(\%)$ & $\mathrm{n}(\%)$ & $\mathrm{n}(\%)$ & \\
\hline 5 years & $48(24.00)$ & $42(26.25)$ & $06(15.00)$ & \\
\hline 6 years & $73(36.50)$ & $58(36.25)$ & $15(37.50)$ & \\
\hline 7 years & $59(29.50)$ & $42(26.25)$ & $17(42.50)$ & \\
\hline 8 years & $20(10.00)$ & $18(11.25)$ & $02(5.00)$ & \\
\hline Sex & $\mathrm{n}(\%)$ & n (\%) & n (\%) & \\
\hline Female & $82(41.00)$ & $62(38.75)$ & $20(50.00)$ & \\
\hline Male & $118(59.00)$ & $98(61.25)$ & $20(50.00)$ & \\
\hline CMPA & $\mathrm{n}(\%)$ & $\mathrm{n}(\%)$ & n (\%) & \\
\hline No & $194(97.00)$ & - & $37(92.50)$ & \\
\hline Yes & $06(3.00)$ & - & $03(7.50)$ & \\
\hline Allergy duration (months) & $40-78$ & - & $40-78$ & \\
\hline mean $\pm S D$ & $1.78 \pm 10.38$ & - & $8.90 \pm 22.01$ & \\
\hline Median & 0 & - & 0 & \\
\hline $\mathrm{LI}$ & n (\%) & n (\%) & $\mathrm{n}(\%)$ & \\
\hline No & $163(81.50)$ & - & $37(92.50)$ & \\
\hline Yes & $37(18.50)$ & - & $03(7.50)$ & \\
\hline Intolerance duration (months) & $12-92$ & - & $12-92$ & \\
\hline mean $\pm S D$ & $9.95 \pm 22.69$ & - & $49.73 \pm 24.43$ & \\
\hline Median & 0 & - & 52 & \\
\hline Systemic diseases & n (\%) & n (\%) & $\mathrm{n}(\%)$ & \\
\hline No & $190(95.00)$ & $153(95.63)$ & $37(92.50)$ & \\
\hline Yes & $10(5.00)$ & $07(4.37)$ & $03(7.50)$ & \\
\hline Use of medication & $\mathrm{n}(\%)$ & $\mathrm{n}(\%)$ & $\mathrm{n}(\%)$ & \\
\hline No & $188(94.00)$ & $155(96.88)$ & $33(82.50)$ & \\
\hline Yes & $12(6.00)$ & $05(3.12)$ & $07(17.50)$ & \\
\hline Dmft & $\mathrm{n}(\%)$ & $\mathrm{n}(\%)$ & $\mathrm{n}(\%)$ & \\
\hline 0 & $118(59.00)$ & $105(65.63)$ & $13(32.50)$ & \\
\hline$>=1$ & $82(41.00)$ & $55(34.37)$ & $27(67.50)$ & $<0.001^{*}$ \\
\hline mean $\pm S D$ & $1.01 \pm 1.69$ & $0.83 \pm 1.60$ & $1.75 \pm 1.84$ & \\
\hline Median & 0 & 0 & 1 & $<0.001^{*}$ \\
\hline \multicolumn{5}{|l|}{ Treatment need } \\
\hline 0 & $123(61.50)$ & $110(68.75)$ & $13(32.50)$ & \\
\hline$>=1$ & $77(38.50)$ & $50(31.25)$ & $27(67.50)$ & $<0.001^{*}$ \\
\hline mean $\pm S D$ & $0.88 \pm 1.63$ & $0.71 \pm 1.62$ & $1.58 \pm 1.50$ & \\
\hline Median & 0 & 0 & 2 & $<0.001^{*}$ \\
\hline
\end{tabular}

CMPA: Cow's milk protein allergy; LI: Lactose intolerance; SD: standard deviation; *Significant difference between groups $(p<0.001)$. 
The prevalence of caries in 5-to-8-year-old children with CMPA or LI was $67.50 \%$ and the mean dmft index was 1.75 . Thirteen $(32.50 \%)$ children were caries-free, without any carious lesions, tooth loss due to caries, or tooth restorations (Table 1). The mean number of decayed teeth amounted to 1.30 , accounting for $74.29 \%$ of the $\mathrm{dmft}$ index. The distribution of $\mathrm{dmft}$ and components was not normal (Table 2).

Furthermore, $67.50 \%$ of the population with CMPA or LI required dental treatment but, on average, only 1.58 teeth required treatment (Table 1$)$. There were no treatment needs for prosthetic crown, facet restorations, pulp treatment, and tooth extractions. Restorations of a single facet represented $77.85 \%$ of total treatment needs (Table 3).

\section{FFQ results}

Milk-based products consumed by children included whole milk, semi-skimmed milk, and

Table 2. Distribution of decayed, indicated extraction, filled components and dmft index in children with CMPA or $\mathrm{LI}$ ( $n=40)$. Paraná, Southern Brazil, 2018.

\begin{tabular}{|c|c|c|c|c|c|}
\hline Statistics & Decayed & Missing & Filled & $d m f t$ & $\begin{array}{l}\text { Zero } \\
\text { dmft }\end{array}$ \\
\hline Mean & 1.30 & 0.0 & 0.45 & 1.75 & - \\
\hline Standard deviation & 1.40 & 0.0 & 1.30 & 1.84 & - \\
\hline$\%$ & 74.29 & 0.0 & 25.71 & 100.0 & 32.50 \\
\hline Minimum & 0.0 & 0.0 & 0.0 & 0.0 & - \\
\hline 25\% Quartile & 0.5 & 0.0 & 0.5 & 0.0 & - \\
\hline Median & 1.0 & 0.0 & 0.0 & 1.0 & - \\
\hline 75\% Quartile & 2.0 & 0.0 & 0.5 & 2.5 & - \\
\hline Maximum & 6.0 & 0.0 & 7.0 & 7.0 & - \\
\hline
\end{tabular}

CMPA: Cow's milk protein allergy; LI: Lactose intolerance.

Table 3. Dental treatment need in children with CMPA or LI $(n=27)$. Means (in teeth) per individual, standard deviation, percentage rates, and sum. Paraná, Southern Brazil, 2018.

\begin{tabular}{lcccc}
\hline \multirow{2}{*}{ Statistics } & Restoration & Restoration & Total & $\begin{array}{c}\text { Zero } \\
\text { ITN }\end{array}$ \\
\cline { 2 - 3 } (one surface) & (two surfaces or more) & & ITn \\
Mean & 1.23 & 0.35 & 1.58 & - \\
SD & 1.33 & 0.74 & 1.50 & - \\
$\%$ & 77.85 & 22.15 & 100.0 & 32.50 \\
Sum & 49 & 14 & 63 & - \\
\hline
\end{tabular}

CMPA: Cow's milk protein allergy; LI: Lactose intolerance; SD: standard deviation. skimmed milk; plain yogurt or fruit yogurt; lactosefree milk (LFM); and soy milk fruit juice (SJ). LFM and SJ had the highest consumption by children with CMPA, representing $65.00 \%$ and $40.00 \%$, respectively (Table 4).

Table 4 shows the differences in consumption patterns between children with and without CMPA/ LI. As expected, allergic or lactose-intolerant children consumed milk-based foods less frequently and replacement foods (LFM) more frequently than did those without CMPA or LI ( $p<0.001)$. High or moderate consumption of foods such as chocolate milk, whole soy milk, soy milk powder, soy yogurt, chocolate soy milk, and other types of milk was not higher than $15 \%$ between the groups.

\section{Association between oral health status and food consumption}

The prevalence of dental caries, treatment needs, and $\mathrm{dmft}$ and ITN indices were compared to health conditions in three different ways. The first one consisted of the analysis of caries incidence and of treatment needs, classified as either absent $(\mathrm{dmft} /$ ITN $=0)$ or present $(\mathrm{dmft} / \mathrm{ITN}>=1)$. The second one consisted in testing caries severity calculated by the mean $\mathrm{dmft}$ and ITN indices. The statistical analysis revealed a significant association between the prevalence of caries and treatment needs and between the $\mathrm{dmft}$ and ITN indices (Table 1). Children with CMPA/LI had a higher caries prevalence rate and need for treatment when compared to those without such health conditions $(p<0.001)$. The third type of analysis consisted in testing oral health status calculated by the mean $\mathrm{dmft}$ and ITN indices with regard to the foods most frequently consumed by children with and without CMPA/ LI. No statistically significant difference was detected between the $\mathrm{dmft}$ index and the milkbased products most frequently consumed by children with CMPA/LI. However, a higher ITN index $(p<0.005)$ was observed for children who consumed soy milk fruit juice. This finding is related to treatment needs, which were 3.5 times greater when children with CMPA/LI with a high food intake were compared to those children without these types of food intolerance (Table 4). 
- Caries in children with lactose intolerance and cow's milk protein allergy

Table 4. Frequency of food intake of children's formulas ( $n=200)$. Paraná, Southern Brazil, 2018.

\begin{tabular}{|c|c|c|c|c|}
\hline Food groups & Total $(n=200)$ & $\begin{array}{l}\text { Children without CMPA }+\mathrm{LI} \\
\qquad(\mathrm{n}=160)\end{array}$ & $\begin{array}{l}\text { Children with CMPA + LI } \\
(\mathrm{n}=40)\end{array}$ & $\mathrm{p}$-value \\
\hline WM/SSM/SM & n (\%) & n (\%) & n (\%) & \\
\hline High & $117(58.50)$ & $113(70.63)$ & $04(10.00)$ & $<0.001^{*}$ \\
\hline Moderate & $42(21.00)$ & $29(18.12)$ & $13(32.50)$ & \\
\hline Low & $41(20.50)$ & $18(11.25)$ & $23(57.50)$ & \\
\hline \multirow{4}{*}{ dmft (high) } & mean $\pm S D$ & mean $\pm S D$ & mean $\pm S D$ & \\
\hline & $0.79 \pm 1.58$ & $0.78 \pm 1.60$ & $1.25 \pm 0.96$ & \\
\hline & Median & Median & Median & \\
\hline & 0 & 0 & 1.5 & 0.110 \\
\hline \multirow{4}{*}{ Treatment need (high) } & mean $\pm S D$ & mean $\pm S D$ & mean $\pm S D$ & \\
\hline & $0.72 \pm 1.67$ & $0.68 \pm 1.67$ & $1.75 \pm 1.26$ & \\
\hline & Median & Median & Median & \\
\hline & 0 & 0 & 2 & $0.027^{*}$ \\
\hline $\mathrm{PY} / \mathrm{FY}$ & n (\%) & n (\%) & $\mathrm{n}(\%)$ & \\
\hline High & $17(8.50)$ & $16(10.00)$ & $01(2.50)$ & \\
\hline Moderate & $89(44.50)$ & $72(45.00)$ & $17(42.50)$ & 0.228 \\
\hline Low & $94(47.00)$ & $72(45.00)$ & $22(55.00)$ & \\
\hline \multirow{4}{*}{ dmft (high + mild) } & mean $\pm S D$ & mean $\pm S D$ & mean $\pm S D$ & \\
\hline & $0.99 \pm 1.74$ & $0.77 \pm 1.69$ & $2.06 \pm 1.66$ & \\
\hline & Median & Median & Median & \\
\hline & 0 & 0 & 2 & $<0.001^{*}$ \\
\hline \multirow{4}{*}{$\begin{array}{l}\text { Treatment need (high + } \\
\text { mild) }\end{array}$} & mean $\pm \mathrm{SD}$ & mean $\pm S D$ & mean $\pm S D$ & \\
\hline & $0.92 \pm 1.91$ & $0.72 \pm 1.92$ & $1.89 \pm 1.60$ & \\
\hline & Median & Median & Median & \\
\hline & 0 & 0 & 2 & $<0.001^{*}$ \\
\hline LFM & n (\%) & n (\%) & n (\%) & \\
\hline High & 37 (18.50) & $11(6.88)$ & $26(65.00)$ & $<0.001^{*}$ \\
\hline Moderate & $04(2.00)$ & $01(0.62)$ & $03(7.50)$ & \\
\hline Low & 159 (79.50) & $148(92.50)$ & $11(27.50)$ & \\
\hline \multirow{4}{*}{ dmft (high) } & mean $\pm \mathrm{SD}$ & mean $\pm \mathrm{SD}$ & mean $\pm S D$ & \\
\hline & $1.65 \pm 1.87$ & $0.82 \pm 0.87$ & $2.00 \pm 2.08$ & \\
\hline & Median & Median & Median & \\
\hline & 1 & 1 & 2 & 0.129 \\
\hline \multirow{4}{*}{ Treatment need (high) } & mean $\pm S D$ & mean $\pm \mathrm{SD}$ & mean $\pm \mathrm{SD}$ & \\
\hline & $1.41 \pm 1.57$ & $0.64 \pm 1.03$ & $1.73 \pm 1.66$ & \\
\hline & Median & Median & Median & \\
\hline & 1 & 0 & 2 & $0.041^{*}$ \\
\hline SJ & $n(\%)$ & n (\%) & n (\%) & \\
\hline High & $70(35.00)$ & $54(33.75)$ & $16(40.00)$ & 0.578 \\
\hline Moderate & 37 (18.50) & 23 (14.37) & $14(35.00)$ & \\
\hline Low & $93(46.50)$ & $83(51.88)$ & $10(25.00)$ & \\
\hline \multirow{4}{*}{ dmft (high) } & mean $\pm S D$ & mean $\pm S D$ & mean $\pm S D$ & \\
\hline & $2.09 \pm 2.27$ & $1.87 \pm 2.23$ & $2.81 \pm 2.32$ & \\
\hline & Median & Median & Median & \\
\hline & 1 & 1 & 3 & 0.115 \\
\hline \multirow{4}{*}{ Treatment need (high) } & mean $\pm \mathrm{SD}$ & mean $\pm S D$ & mean $\pm S D$ & \\
\hline & $1.87 \pm 2.28$ & $1.69 \pm 2.42$ & $2.50 \pm 1.67$ & \\
\hline & Median & Median & Median & \\
\hline & 1 & 1 & 3 & $0.017^{*}$ \\
\hline
\end{tabular}

CMPA: Cow's milk protein allergy; FY: fruit yogurt; LFM: lactose-free milk; LI: Lactose intolerance; PY: plain yogurt; SD: standard deviation; SJ: soy milk fruit juice; SM: skimmed milk; SSM: semi-skimmed milk; *Significant difference between groups $(p<0.05)$. 


\section{Discussion}

The present study on dental caries, treatment needs, and their relationship with medical and nutritional factors in children with CMPA or LI reveals high caries prevalence and dental treatment rates. However, these needs are easily solved through clinical procedures of low complexity.

Globalization and neoliberal policies adopted by large multinational food manufacturers have led to the higher and early consumption of processed food by children. ${ }^{26}$ Consumption trends emerge mainly among children with special allergic and food intolerance conditions. This provides new room for the development of epidemiological studies for the identification of population groups at high risk for dental caries. Since the pattern of caries development has undergone several changes in an era characterized by industrialized food, in-depth studies are required so that children with special health needs and the respective stages of the disease can be followed up. This would contribute towards the establishment of prevention policies, health promotion, and control and treatment of the main oral diseases.

Although dental caries is the oral disease most widely investigated worldwide, most of the research focuses on children without CMPA/LI. Specific data on this population are lacking, even in the case of industrialized countries. In fact, the few epidemiological studies at hand refer to the consumption of soy-based foods ${ }^{18}$ and of lactose-free milk. ${ }^{19}$

By comparing the results of the present research to those of a study of children without CMPA/LI in government-run schools in Araçatuba, Brazil, in $2010,{ }^{27}$ caries prevalence $(67.50 \%)$ was higher in this study than the rate (44.70\%) obtained for 4-to-6-yearold children in that study.

Mean $\mathrm{dmft}$ rates in the same study for 5- and 6-year-old children were respectively 1.65 and 1.72, lower than the 1.75 index observed in the current analysis. Results are worse when compared to the national data from SB Brasil 2010. ${ }^{28}$ In the case of 5 -year-old children, caries prevalence was as high as $83.62 \%$, with a mean $\mathrm{dmft}$ index of 2.43 . It should be underscored that the current research evaluated 5-to-8-year-old children from a private school, who, allegedly, have a better socioeconomic background and higher parental schooling than those in governmentrun schools.

Dental caries was the main component of the $\mathrm{dmft}$ index in children with CMPA/LI, which amounted to $74.29 \%$, corroborating the $80.20 \%$ rate obtained by the National Research on Oral Health of Brazilian populations. ${ }^{28}$ Results demonstrate that these children did not have access to dental services.

Also, results show that seven children $(17.50 \%)$ with CMPA/LI and caries had a dmft index $\geq 4$. These children make up a representative group which needs dental treatment, or rather, they constitute an epidemiological polarization group. These findings reveal that children with CMPA/LI need prevention programs for caries and more dental care.

The current study evidenced an association between dental caries and treatment needs for primary dentition and CMPA/LI. There was, however, no significant association between dental caries and the large consumption of foods, lactose-free milk, and soy milk fruit juice by children with CMPA/LI. In fact, Carvalho et al.$^{18}$ reported a relationship between dental fluorosis and LI in a group of 26 kindergarten children aged 4-6 years ( $p<0.05)$, but no association with soy-based products consumed by these children.

Contrastingly, Cagetti et al. ${ }^{19}$ detected a $42.31 \%$ caries prevalence in schoolchildren aged 6-8 years and associated the ingestion of lactose-free milk with moderate caries presence $(p=0.02)$, benchmarked by the International Caries Assessment and Detection System (ICDAS). Therefore, further epidemiological studies of children with CMPA/LI from different countries and including other samples should be performed to evaluate the different risks for oral disease among these children.

The oral health of children with CMPA/LI proved to be worse when compared to that of children without CMPA/LI due to dietary restrictions on an important source of calcium (cow's milk) and to the replacement of industrialized soy-based foods with sugar-rich and low $\mathrm{pH}$ products, which may potentiate the enamel demineralization in the primary dentition, ${ }^{13}$ in addition to tooth erosions. ${ }^{29}$ However, one should bear in mind the current limited knowledge on the epidemiological pattern of caries in children allergic 
to other types of food and whose food consumption is hypothetically different from that of children with CMPA/LI. Another limitation in the present study was the use of a validated FFQ, rarely used in dentistry, without further details on potentially cariogenic foods.

The results highlight the importance of dental caries prevention in children with CMPA/LI. Prevention programs should also be targeted at other specific groups. The best strategy relies on different diagnostic, cultural, economic, and geographic factors, among others. Some strategies could include the use of fluoride, chlorhexidine-based mouth rinses, and sealants, in addition to motivational, behavioral, and collective activities. The early identification of groups at high risk for dental caries in prevention programs should be enhanced, ${ }^{27,30,31}$ combined with the

\section{References}

1. National Institute for Health and Care Excellence. Food allergy in children and young people: diagnosis and assessment of food allergy in children and young people in primary care and community settings CG 116. London: National Institute for Health and Care Excellence; 2011 [cited 2017 Dec 14]. Available from: https://www.nice.org.uk/ guidance/cg116/evidence/full-guideline-136470061

2. Zhu J, Pouillot R, Kwegyir-Afful EK, Luccioli S, Gendel SM. $A$ retrospective analysis of allergic reaction severities and minimal eliciting doses for peanut, milk, egg, and soy oral food challenges. Food Chem Toxicol. 2015 Jun;80:92-100. https://doi.org/10.1016/i.fct.2015.02.023

3. Nwaru BI, Hickstein L, Panesar SS, Muraro A, Werfel T, Cardona $V$ et al. The epidemiology of food allergy in Europe: a systematic review and meta-analysis. Allergy. 2014 Jan;69(1):62-75. https://doi.org/10.1111/all.12305

4. Luyt D, Ball H, Makwana N, Green MR, Bravin K, Nasser SM et al. $\mathrm{BSACl}$ guideline for the diagnosis and management of cow's milk allergy. Clin Exp Allergy. 2014;44(5):642-72. https://doi.org/10.1111/cea.12302

5. Nosan G, Jakic M, Jager M, Paro-Panjan D. Prognostic accuracy of clinical signs and diagnostic tests in cow's milk allergy in newborns. Pediatr Neonatol. 2017 Oct;58(5):44954. https://doi.org/10.1016/i.pedneo.2016.09.009

6. Sampson HA. Food allergy: past, present and future. Allergol Int. 2016 Oct;65(4):363-9. https://doi.org/10.1016/i.alit.2016.08.006 establishment of public policies for caries reduction, increasing the access to oral health services. ${ }^{32}$

\section{Conclusions}

Prevalence and severity of dental caries and treatment needs in primary dentition in children were associated with CMPA and LI. The consumption of replacement foods by children with CMPA/LI did not cause the development of carious lesions. However, this special health condition should be taken into account when planning cure, prevention, and educational programs on oral health for children within the age bracket investigated herein.

\section{Acknowledgements}

The authors thank CAPES for financial support.

7. Eigenmann PA. Mechanisms of food allergy.

Pediatr Allergy Immunol. 2009 Feb;20(1):5-11. https://doi.org/10.1111/i.1399-3038.2008.00847.x

8. Walsh J, Meyer R, Shah N, Quekett J, Fox AT. Differentiating milk allergy ( $\mathrm{g} E$ and non-lgE mediated) from lactose intolerance: understanding the underlying mechanisms and presentations. Br J Gen Pract. 2016 Aug;66(649):e609-11. https://doi.org/10.3399/bigp16X686521

9. Fiocchi A, Brozek J, Schünemann H, Bahna SL, Berg A, Beyer $\mathrm{K}$ et al. World Allergy Organization (WAO) diagnosis and rationale for action against cow's milk allergy (DRACMA) guidelines. World Allergy Organ J. 2010 Apr;3(4):57-161. https://doi.org/10.1097/WOX.0b013e3181defeb9

10. Mattar R, Mazo DF. [Lactose intolerance: changing paradigms due to molecular biology]. Rev Assoc Med Bras (1992). 2010 Mar-Apr;56(2):230-6. https://doi.org/10.1590/S0104-42302010000200025

11. Lomer MC, Parkes GC, Sanderson JD. Review article: lactose intolerance in clinical practice-myths and realities. Aliment Pharmacol Ther. 2008 Jan;27(2):93-103. https://doi.org/10.1111/j.1365-2036.2007.03557.x

12. Mofidi S. Nutritional management of pediatric food hypersensitivity. Pediatrics. 2003 Jun;111(6 Pt 3):1645-53.

13. de Mazer Papa AM, Tabchoury CP, Del Bel Cury AA, Tenuta LM, Arthur RA, Cury JA. Effect of milk and soy-based infant formulas on in situ demineralization of human primary enamel. Pediatr Dent. 2010 Jan-Feb;32(1):35-40. 
14. Moursi AM, Fernandez JB, Daronch M, Zee L, Jones CL. Nutrition and oral health considerations in children with special health care needs: implications for oral health care providers. Pediatr Dent. 2010 Jul-Aug;32(4):333-42.

15. Amaral CO, Straioto FG, Napimoga MH, Martinez EF. Caries experience and salivary aspects in individuals with fragile X syndrome. Braz Oral Res. 2017 Sep;31(0):e79. https://doi.org/10.1590/1807-3107bor-2017.vol31.0079

16. Boyd LD, Palmer C, Dwyer JT. Managing oral health related nutrition issues of high risk infants and children. J Clin Pediatr Dent. 1998;23(1):31-6.

17. Maslin K, Grundy J, Glasbey G, Dean T, Arshad SH, Grimshaw K et al. Cows' milk exclusion diet during infancy: is there a long-term effect on children's eating behaviour and food preferences? Pediatr Allergy Immunol. 2016 Mar;27(2):141-6. https://doi.org/10.1111/pai.12513

18. Carvalho CA, Zanlorenzi Nicodemo CA, Mercadante DCF, Carvalho FS, Buzalaf MA, Sales-Peres SHC. Dental fluorosis in the primary dentition and intake of manufactured soybased foods with fluoride. Clin Nutr. 2013 Jun;32(3):432-7. https://doi.org/10.1016/i.clnu.2012.09.006

19. Cagetti MG, Congiu G, Cocco F, Meloni G, Sale S, Campus G. Are distinctive risk indicators associated with different stages of caries in children? A cross-sectional study. BMC Public Health. 2016 Dec;16(1):1213. https://doi.org/10.1186/s12889-016-3865-4

20. Vandemplas Y. Lactose intolerance. Asia Pac J Clin Nutr. 2015;24 Suppl 1:S9-13. https://doi.org/10.6133/apicn.2015.24.s1.02

21. Pretto FM, Silveira TR, Menegaz V, de Oliveira J. [Lactose malabsorption in children and adolescents: diagnosis through breath hydrogen test using cow milk]. J Pediatr (Rio J). 2002 MayJun;78(3):213-8. Portuguese. https://doi.org/10.2223/JPED.833

22. Peres MA, Traebert J, Marcenes W. [Calibration of examiners for dental caries epidemiologic studies]. Cad Saude Publica. 2001 Jan-Feb;17(1):153-9. https://doi.org/10.1590/S0102-311X2001000100016

23. Slater B, Philippi ST, Fisberg RM, Latorre MR. Validation of a semi-quantitative adolescent food frequency questionnaire applied at a public school in São Paulo,
Brazil. Eur J Clin Nutr. 2003 May;57(5):629-35. https://doi.org/10.1038/sj.ejcn.1601588

24. Marchioni DM, Voci SM, Lima FE, Fisberg RM, Slater B. Reproducibility of a food frequency questionnaire for adolescents. Cad Saude Publica. 2007 Sep;23(9):2187-96. https://doi.org/10.1590/S0102-311X2007000900026

25. World Health Organization. Oral health surveys, basic methods. 4th ed. Geneva: Print Reports; 1997.

26. Thomson WM. Tackling the Wicked Health Problem of Early Childhood Caries. Pesqui Bras Odontopediatria Clin Integr. 2018;18(1):e3943. https://doi.org/10.4034/PBOCI.2018.181.ed1

27. Borges HC, Garbín CA, Saliba O, Saliba NA, Moimaz SA. Socio-behavioral factors influence prevalence and severity of dental caries in children with primary dentition. Braz Oral Res. 2012 Nov-Dec;26(6):564-70. https://doi.org/10.1590/S1806-83242012000600013

28. Ministério da Saúde (BR). Secretaria de Atenção à Saúde. Projeto SB Brasil 2010. Condições de saúde bucal da população brasileira 2010: resultados principais. Brasília, DF: Ministério da Saude; 2011 [cited 2018 Mar 2]. Available from:.http://bvsms.saude.gov.br/bvs/publicacoes/pesquisa_ nacional_saude_bucal.pdf

29. Torres CP, Chinelatti MA, Gomes-Silva JM, Rizóli FA, Oliveira MA, Palma-Dibb RG et al. Surface and subsurface erosion of primary enamel by acid beverages over time. Braz Dent J. 2010;21(4):337-45. https://doi.org/10.1590/S0103-64402010000400009

30. Santos AP, Séllos MC, Ramos ME, Soviero VM. Oral hygiene frequency and presence of visible biofilm in the primary dentition. Braz Oral Res. 2007 Jan-Mar;21(1):64-9. https://doi.org/10.1590/S1806-83242007000100011

31. Moimaz SA, Borges HC, Saliba O, Garbin CA, Saliba NA. Early childhood caries: epidemiology, severity and sociobehavioural determinants. Oral Health Prev Dent. 2016;14(1):77-83.

32. Corrêa-Faria P, Paixão-Gonçalves S, Paiva SM, Pordeus IA. Incidence of dental caries in primary dentition and risk factors: a longitudinal study. Braz Oral Res. 2016;30(1):e59. https://doi.org/10.1590/1807-3107BOR-2016.vol30.0059 